\title{
Raimo Jaakkola
}

\section{Aikuisten opintoaktiviteetin tutkimisesta}

\begin{abstract}
Jaakkola, Raimo 1986. Aikuisten opintoaktiviteetin tutkimisesta. Aikuiskasvatus 6, 3, 143-145. - Opintoaktiivisuutta tarkastellaan siihen virittymisen ja sen pysyvyyden tai sen muuttumisen suhteen. Opettajien nähdään monasti yliarvioivan opiskelijoiden oppimisvalmiudet, unohtavan opiskelijoiden puutteelliset perustiedot sekä etenevän opetuksessaan liian nopeasti.
\end{abstract}

\section{Yleistä}

Aikuisten opintoaktiivisuuteen, opintoihin osallistujien tavoitteiden muotoutumiseen, osallistumisen säännöllisyyteen ja intensitettiin vaikuttavien psykologisten ja sosiologisten tekijöiden suhteiden tutkiminen ja selvittäminen on yksi keskeinen alue, jossa voidaan yhdistää aikuiskasvatuksen teoreettinen tutkimus hedelmällisesti käytännön toiminnassa esiintyviin opinto-organisaation ja opetuksen kehittämisen ongelmiin.

Huolimatta siitä, että aikuisten opintoihin osallistumis- ja opintokäyttäytymistutkimuksilla on ollut pitkäaikainen ja näkyvä paikka aikuiskasvatuksen tutkimuksessa, on alan tutkimuskirjallisuudesta havaittavissa, että opintoaktiivisuutta kuvaava käsitteistö on sekavaa ja suurin osa tehdyistä empiirisistä tutkimuksista on vailla riittävää teoreettista pohdintaa. Muutamaa poikkeusta lukuunottamatta tutkimukset ovat kuvailevia ja rajoittuneet käsittelemään vain joitakin psykologisia tai sosiaalisia taustamuuttujia. Tutkimukset näyttävät replikoivan suoraan aikaisempien tutkimusten tutkimusotetta, jolloin teoreettiset selitysmallit opintoaktiivisuuden luonteesta ovat jääneet epäkumulatiivisiksi, niissä ei ole pystytty hyödyntämään riittävästi uusia näkökulmia ja yksittäisiä tutkimustuloksia. Osittain syynä ovat olleet ongelman monitasoisuudesta ja monimuotoisuudesta johtuvat lähestymistavalliset vaikeudet; miten hyödynnetään ja yhdistetään aikuiskasvatuksen ongelmiin psykologian, sosiologian tai muiden tieteiden teoreettisia saavutuksia tai lähestymistapoja johdonmukaiseksi kokonaisuưdeksi.

\section{Käytetyt lähestymistavat}

Opintoaktiivisuuden tutkimuksessa voidaan havaita kolme erityyppistä lähestymistapaa. Ensinnäkin sosiologiset, yhteiskunnan rakenteista lähtevät selitysmallit, joissa puhtaimmillaan on pyritty palauttamaan osallistumisen ja opintoaktiivisuuden problematiikka suoraan yhteiskunnan taloudellisiin ja sosiaalisiin rakenteisiin. Toiseksi, ikäänkuin vastapainoksi edelliselle, opintoaktiivisuutta on lähestytty puhtaasti yksilöpsykologisena ilmiönä, jolloin aktiivisuuden selittämisen lähtökohtana ovat olleet yksilön persoonallisuuden piirteet tai motivaatio-tekijät ilman kytkentää aikuisen elämäntilanteeseen tai opiskelussa esiintyvien organisatorisiin tai didaktisiin ongelmiin.

Kolmantena lähestymistapana voidaan pitää laaja-alaisia kompleksisia malleja, joille on ominaista pyrkimys jäsentää keskeisiä opintoaktiivisuutta selittäviä tekijöitä niiden vaikutusprosessin suuntaisesti. Koska opintoaktiivisuuden viriämiseen ja sen kehittymiseen opiskelun kuluessa vaikuttavat eritasoiset tekijät, näistä malleista on muodostunut hyvin monimutkaisia, ja niiden hallinta käytännön tutkimustyössä on ongelmallista. 


\section{Eräs yritys opinto- aktiivisuuden selvittämiseksi}

Omassa valmisteilla olevassa tutkimuksessani olen keskittynyt lähinnä kahteen asiaan. Ensinnäkin opintoaktiivisuuden virittymiseen, ts. siihen mitkä tekijät herättävät kiinnostuksen opiskeluun siten, että henkilö ryhtyy harjoittamaan aikuisopintoja, ja toiseksi opintoaktiivisuuden pysyvyyteen tai sen muuttumiseen opiskeluaikana. Pyrkimyksenä on saada tarkempaa tietoa siitä, mitkä tekijät vaikuttavat opintoihin osallistumisen jatkuvuuteen, säännöllisyyteen tai opiskeluun intensiteettiin sekä millaisia muutoksia opintoaktiivisuudessa on havaittavissa opiskelun kuluessa.

Opintoaktiivisuuden virittymistä ja sen pysymistä on tarkoitus selittää kolmentyyppisillä tekijöillä: 1) Yksilön elinolosuhteisiin liittyvillä tekijöillä, joita ovat mm. työ-, koti- ja opiskeluolosuhteet ja vapaa-ajan toimintojen suuntautuminen, 2) yksilön persoonallisuustekijöillä, joita ovat mm. henkilön ammatillinen, opinnollinen ja muu kokemustausta, kyvyt, minäkuva, koettu nykyinen elämäntilanne, elämäntavan suuntautuminen ja ammatilliset ym. elämänsuunnitelmat, ja 3) opinto-organisaatioon ja opetukseen liittyvillä tekijöillä, joita ovat mm. opinto-organisaation antama tieto opiskelun tavoitteista, toimintamuodoista, opiskeluvaatimuksista sekä tiedot opetuksen aikana käytössä olleista didaktisista järjestelyistä ja opetuksen sisällön ja toteutuksen laadullisista piirteistä.

Opintoaktiivisuuden virittymisen lähtökohta on se, että aikuinen henkilö arvioi itse omia tarpeitaan ja käyttäytymisensä tavoitteita ja omaa konkreettista tilannettaan. Mikäli omien tarpeiden ja nykyisen tilanteen välillä on ristiriita hän virittyy ratkaisemaan sen arvioimalla omia kykyjään ja mahdollisuuksiaan saavuttaa tarpeensa. Kun henkilö saa tietoa opetuksen tavoitteista, toimintamuodoista ja -tavoista hän muodostaa oman kokemuksensa ja tietämyksensä kautta käsitykset opetuksen merkityksestä, mahdollisuuksista osallistua opetukseen, onko hänellä oppimiskykýnsä riittävä tai onko hänellä mahdollisuuksja läpäistä asetetut opinnolliset vaatimukset jne.

Aikuisten opintoaktiivisuustutkimuksen eräs keskeinen ongelma on se, kuinka hyvin me tiedämme ne odotukset ja opiskelutarpeet, joita aikuisilla henkilöillä on tällä hetkellä nykyisessä yhteiskunnassa. Itse aikuisuus yhdistää ihmisiä vähän, vähemmän kuin muut ikä- kaudet. Aikuisen oppimisen pääsuuntaajana on elämän kokonaistilanne: elettävä elämänvaihe, sen objektiiviset puitteet, koettu ongelma. Aikuisten intressit ja kiinnostukset ovat sidoksissa yksilöiden elinehtoihin ja -olosuhteisiin, jotka määrittävät sitä, mitä mahdollisuuksia yksilöillä on suunnitella ja toteuttaa omaa tulevaisuuttaan tai millaisia konkreettisia opiskelutarpeita heille muotoutuu. Tällä hetkellä meillä on liian vähän tietoa siitä, miten erilaisissa sosiaalisissa ympäristöissä ja elämäntilanteissa aikuisten opinnolliset tarpeet muuttuvat ja kehittyvät sekä miten aikuiskoulutuksen organisaatiot ovat pyrkineet vastaamaan yhteiskunnallisen muutoksen aiheuttamiin haasteisiin. On ilmeisen selvää, että tarvitaan enemmän sellaista tutkimusta, jossa pyritään selvittämään entistä tarkemmin ja laajaalaisemmin aikuisten elämäntilanteiden, tarpeiden ja intressien sekä opinto-käyttäytymisen yhteyksiä.

Toinen ongelma opintoaktiivisuustutkimuksessa on se, että meillä ei ole riittävää systemaattista tietoa miten erilaiset yksilölliset kokemustaustat, kyvyt, minäkuva jne. vaikuttavat opintoaktiivisuuden virittymiseen tietyssä elämäntilanteessa, kuinka erilaisen oppimistaustan tai minäkäsityksen omaavat henkilöt arvioivat mahdollisuuksiaan menestyä opinnoissa tai kuinka realistisia opinnollisia tavoitteita eri henkilöryhmät asettavat omille opinnoilleen. Alustavien tulosten perusteella voidaan todeta esimerkiksi se, että ammatillisessa aikuiskoulutuksessa heikon opinnollisen minäkuvan ja heikommat opiskeluvalmiudet omaavat henkilöt asettavat muita useammin itselleen epärealistisia odotuksia siitä, mikä on opintojen todellinen vaikutus omien ammatillisten suunnitelmien toteutumiselle.

Opintoaktiivisuuden pysymisen tai muuttumisen selittämisessä pääpaino on opinto-organisaatioon ja opetukseen liittyvillä tekijöillä. Nämä tekijät voidaan jakaa kolmeen ryhmään: 1) opetussuunnitelmien tavoitteet ja sisällöt, kuinka hyvin annettu opetus sisällöllisesti vastaa opiskelijoiden odotuksia; missä määrin opiskelijat pystyvät hyödyntämään opetuksen sisältöä lyhyellä aikavälillä omiin tavoitteisiinsa ja suunnitelmiinsa ja mikä merkitys näillä asioilla on opiskelun jatkuvuuteen ja säännöllisyyteen, 2) mikä merkitys opintoaktiivisuuden pysymiseen on erilaisilla didaktisilla järjestelyillä; kuinka opetuksessa otetaan huomioon aikuisen oppimisen erityispiirteet, hyödynnetään aikaisemmin hankittuja ammatillisia kokemuksia, kuinka huomioidaan opetuksen yhteydessä aikuisten erilaiset 
oppimisvalmiudet jne. ja 3) mikä vioivat opiskelijoiden oppimisvalmiudet. Lämerkitys opetuksen puitetekijöillä (tiloilla, hes puolella aikuisopiskelijoista niin opetusajan-kohdalla jne.) on ámmatilli-sessa kuin yleissivistävissäkin opintoaktiivisuuden pysymi-seen. opinnoissa on ongelmia opetettavan asian Edellä mainittujen opinto-organisaatioon ja omaksumisessa, muistiinpanojen tekemisessä opetukseen liittyvien tekijöiden lisäksi tarkoi- tai uusien asiain kytkemisessä aikaisempiin, tuksena on selvittää mitä esteitä eri sosiaaliset usein puutteellisiin perustietoihinsa. Toiseksi olosuhteet aiheuttavat aktiiville opintoihin osallistumiselle.

erityisesti ammatilli-sessa koulutuksessa opetuksen etenemisvauhti on sellainen, että opiskelijalle jää liian vähän aikaa uuden oppiaineksen jäsentämiselle, sen kertaamiselle ja liittämiselle aikaisemmin opittuun asiaan. Tähän seikkaan tulisi kiinnittää opetuksessa vakavaa huomiota. 